\title{
INFECÇÃO PELO PLASMODIUM FALCIPARUM E GRAVIDEZ. RELATO DE CASOS
}

\section{Domingos Alves Meira}

\begin{abstract}
Em 1982 e em 1985 foram observados em Humaitá, Estado do Amazonas, respectivamente, uma crianca lactente e uma gestante tercigesta, no segundo trimestre da gravidez, ambas com malária pelo Plasmodium falciparum. O lactente, masculino, natural do Amazonas tinha um mês de idade e apresentava malária desde o décimo dia após o nascimento. Sua mãe tinha 19 anos, era natural do Amazonas e apresentara a primo-infecção palustre no dia do parto, desse que era o seu segundo filho. O outro caso era o de uma gestante com 22 anos, natural do Amazonas, que tinha 2 filhos, um de 8 e outro de 6 anos e apresentara três surtos prévios de malária, o primeiro em 1983 e o último em março de 1985. Quando foi atendida estava com malária e no $2^{\circ}$ trimestre da gestação. Tanto o lactente, quanto a gestante foram tratados com clindamicina $e$ tiveram cura clínica e parasitária. O lactente provavelmente apresentou malária congênita, ou intraparto, pelo curto período de incubação, que apresentou. Ao contrário do que tem sido descrito em áreas hiperendêmicas a gestante apresentou malária na terceira gestação, embora tenha se comportado como primigesta, do ponto de vista da imunidade, pois os surtos prévios que teve ocorreram após as gestações anteriores.
\end{abstract}

Palavras-chaves: Malária, Gravidez. Plasmodium falciparum.

A malária, nas regiões hiperendêmicas, é mais prevalente e intensa nas gestantes do que entre as outras mulheres da população geral e da mesma faixa etária 35691015 . É possivel que a gravidez diminua a memória imune, adquirida pelas experiências prévias com a malária, em virtude das modificações imunológicas complexas, que ocorrem durante esse periodo 410 e que levam à imunodepressão.

Por outro lado, as infecções congênitas são raras em áreas hiperendêmicas 10 , talvez em virtude de fatores malariostáticos que poderiam reduzir a reprodução parasitária no recém-nascido, tais como: os anticorpos adquiridos transplacentariamente ${ }^{14}$, hemogiobina $F$, população eritrocitária idosa e dieta pobre em ácido para-aminobenzóico ${ }^{10}$.

O objetivo desse trabalho foi o de apresentar as observações feitas em dois casos de malária e suas repercussōes na gravidez, na região de Humaitá, Estado do Amazonas.

Trabalho da Faculdade de Medicina, Campus de Botucatu, UNESP, com auxílio do CNPq (Proc. no 40.0755/85 PIDE VI).

Endereço para correspondència: Prof. Domingos Alves Meira. Departamento de Moléstias Infecciosas e Parasitarias, Dermatologia e Radiologia da Faculdade de Medicina de Botucatu, UNESP, Campus de Botucatu, São Paulo, CP: 522- 18600 Botucatu, SP.

Recebido para publicação em 14/12/87.

\section{CASUÍSTICA}

Caso 1 - Em setembro de 1982 foi atendida uma criança lactente, com um mès de idade, do sexo masculino, natural de Guariba, no Rio Aripuanã, situado no municipio de Aripuanã, no Estado do Amazonas. Dez dias após o nascimento, a criança adoeceu com febre, anorexia e diarréia. Persistiu com essa sintomatologia até o dia da consulta, ocasião em que se constatou no exame fisico regular estado geral, mal estado nutritivo, temperatura axilar de $37,2^{\circ} \mathrm{C}$, freqüência cardiaca de 120 bat./min., freqüência respiratória de $32 \mathrm{mov} . / \mathrm{min}$., peso de $4.500 \mathrm{~g}$, palidez cutânea e mucosa $(++)$, fígado a $3 \mathrm{~cm}$ do rebordo costal direito, de consistência aumentada e baço a 2 $\mathrm{cm}$ do rebordo costal esquerdo, de consistencia aumentada. A mãe com 19 anos de idade sempre residiu em Guariba e nunca tinha tido malária até o dia do parto. Durante a gestação não apresentou nenhuma doença. Desde o dia do parto vem apresentando crises de malária. As condições de gestação e do parto foram normais. O exame parasitológico de sangue, do lactente, revelou 5.500 trofozoitas e 150 gametócitos de Plasmodium falciparum, por $\mathrm{mm}^{3}$. Foi tratado pela clindamicina, na dose de $20 \mathrm{mg} / \mathrm{kg} /$ dia, pela via oral, em duas tomadas, durante 7 dias. Apresentou melhora clínica desde o $2 \%$ dia de tratamento, com desaparecimento da febre e diarréia. Os trofozoitas desapareceram do sangue periférico no $60^{\circ}$ dia, persistindo apenas gametócitos. Houve diminuição do figado e do baço, por ocasião do término do tratamento. 
Relato de Caso. Meira DA. Infeccâo pelo Plasmodium falciparume gra videz. Relato de casos. Revista da Sociedade Brasileira de Medicina Tropical 22: 99-101, Abr-Jun, 1989

Caso 2 - Em setembro de 1985, foi atendida uma gestante de 22 anos da idade, natural de Manicoré, Estado do Amazonas, e residente às margens da Lagoa do Paraiso, local do provável contágio, distante $15 \mathrm{~km}$ de Humaitá, pela rodovia Transamazônica. Estava doente há 6 dias com crises febris sugestivas de malária e apresentava-se em regular estado geral, com palidez cutâneo-mucosa, consciente, freqüência cardiaca de $120 \mathrm{bat} . / \mathrm{min}$., temperatura axilar de $38,2^{\circ} \mathrm{C}$, tensão arterial de $100 \times 45$, figado palpável a $4 \mathrm{~cm}$ do rebordo costal direito, doloroso à palpação, baço a 15 $\mathrm{cm}$ do rebordo costal esquerdo, doloroso à palpação, $\mathrm{e}$ altura uterina compativel com gravidez de 4 meses. Referia ausência de movimento fetal há 2 dias. Informava ter tido 3 surtos anteriores de malária, o primeiro em 1983 e o último em março de 1985 , tendo sido nessas ocasiōes medicada pela SUCAM. Era tercigesta, sendo que os 2 primeiros filhos tinham 8 e 6 anos de idade. $O$ diagnóstico etiológico foi estabelecido pelo encontro de 360 trofozoitas por $\mathrm{mm}^{3}$ de Plasmodium falciparum. Recebeu tratamento com clindamicina na dose de $20 \mathrm{mg} / \mathrm{kg} / \mathrm{dia}$, pela via intravenosa, em duas tomadas, durante 5 dias. A partir do 2 . dia de tratamento, voltou a sentir movimentos fetais. A febre desapareceu no 3. dia. A parasitemia negativou-se no 5 . dia, enquanto que o baço deixou de ser doloroso à palpação no 4 o dia e diminuiu de tamanho, tornando-se palpável a $6 \mathrm{~cm}$ no $70^{\circ}$ dia.

\section{DISCUSSÃO}

A maioria dos autores 35610 que tem estudado as repercussões da malária na gravidez, em regiões hiperendêmicas, relatam que a doença é mais freqüente e grave em primigestas, principalmente no segundo trimestre, entre a $13{ }^{\mathrm{a}}$ e $16^{\mathrm{a}}$ semanas de gestação. De acordo com Mc Gregor ${ }^{10}$ a imunodepressão da gravidez e um fator de imunidade local, este último representado pelo útero e pela placenta, contribuiriam para explicar tal comportamento. Assim, a primigesta reinfectada em região endêmica teria a imunidade, anteriormente adquirida, diminuida pela gravidez, mas a placenta, ao seqüestrar as hemácias parasitadas 571015 , estimularia pela via celular a imunidade uterina, que aumentaria com as eventuais novas infecções que viessem ocorrer em gestações posteriores ${ }^{10}$. Nesse sentido, Brabin ${ }^{5}$ considera que a gestante, em região endêmica, perde a imunidade no início da gravidez readquirindo-a, no final, com possibilidade de reforçá-la nas próximas gestaçōes. Dessa forma, nas áreas hiperendêmicas de malária, do ponto de vista de imunidade adquirida, as primigestas seriam comparáveis às crianças de até dois anos de idade, e as multigestas, aos escolares.

A placenta é barreira eficaz porque retém notavelmente eritrócitos infectados com formas assexuadas mais maduras do Plasmodium falcipa- rum $^{15}$. Bray $\& \operatorname{Sinden}^{7}$ com base nas observaçōes de Miller e cols ${ }^{11} 1213$, de Aikawa ${ }^{1}$ e nas suas proprias julgam ser possivel que moléculas de IgG possam ligar-se aos "nós" de eritrócitos infectados e aos receptores (FC) dos sinciciotrofoblastos.

O lactente (caso 1) era portador provavelmente de malária congênita, pois adoeceu no 10 \% dia após o nascimento e tendo em vista que a infecção primária é excepcionalmente rara nas duas primeiras semanas de vida $^{10}$, em virtude talvez da participação de fatores malariostáticos já referidos 1014 . O diagnóstico de malária congênita, em regiões endêmicas, é muito dificil de ser estabelecido 810 , pois, quando a doença se manifesta em recém-nascido a partir de 2 semanas de vida, pode também sugerir infecção adquirida. Por outro lado, a mãe dessa criança comportou-se como primigesta sem experiência prévia de malária, pois adoeceu pela primeira vez no dia do parto. Por essa razão, talvez a malária tenha se manifestado precocemente na criança, que não teria recebido anticorpos maternos, sugerindo transmissão congênita, ou pelo menos, intraparto.

A gestante (caso 2), apesar de ser tercigesta, comportou-se como primigesta, pois os surtos de malária que apresentara ocorreram após as 2 gestações que tivera. É importante destacar a grande esplenomegalia que apresentava, compativel com baixa imunidade. Deve ser salientado ainda que ela estava no 2 \% trimestre da gravidez, concordando com os dados referidos na literatura 510 .

Ambos responderam satisfatoriamente ao tratamento pela clindamicina. Esta deve ser uma das indicações principais da clindamicina, isto é, no tratamento de gestantes e de recém-nascidos com infecção pelo Plasmodium falciparum.

\section{SUMMARY}

In 1982 and 1985, an infant and a pregnant woman in the second trimester of her third pregnancy were respectively observed in Humaitá County, State of Amazonas, Brazil. Both had been diagnosed as having Plasmodium falciparum malaria. The infant was a boy born in the State of Amazonas with malaria since the $10^{\text {th }}$ day of life and was examined at one month of age. His mother was 19 years old, was born in the State of Amazonas and had shown primary malarial infection on the day of the delivery of this child, her second. The pregnant woman was 22 years old, was born in the State of Amazonas, had two children respectively aged 8 and 6 years and had suffered three previous bouts of malaria, the first in 1983 and the last in March 1985. Both the infant and the pregnant woman were treated with clindamycin and evolved satisfactorily to clinical and parasitic cure. The infant probably presented with congenital 
Relato de Caso. Meira DA. Infecção pelo Plasmodium falciparum egravidez. Relato de casos. Revista da Sociedade Brasileira de Medicina Tropical 22: 99-101, Abr-Jun, 1989

malaria in view of the short period of incubation, which may have been due to the fact that he did not receive maternal antibodies. falciparum.

Key-words: Malaria. Pregnancy. Plasmodium

\section{REFERÊNCIAS BIBLIOGRÁFICAS}

1. Aikawa M. Variations in structure and function during the life-cicle of malarial parasites. Bulletin of the World Health Organization 55:139-i56, 1977.

2. Aikawa M, Rabbage JR, Welide BT. Functional apparatus in erythrocytes infected with malarial parasites. Zeitschrift fur 7allforschung und Mickroskopische Anatomie 124:72-75, 1972.

3. Archibald HM. The influence of malarial infection of the placenta on the incidence of prematurity. Bulletin of the World Health Organization 15:842-845, 1956.

4. Beer AE, Quebbeman JF, Ayers JWT, Haines R. Major histocompatibility complex antigens maternal and paternal immune responses, and chronic habitual abortions in humans. American Journal of Obstetrics and Gynecology 141:981-999, 1981.

5. Brabin BJ. An analysis of malaria in pregnancy in Africa. Bulletin of the World Health Organization 61:1005-1016, 1983.

6. Bray RS, Anderson MJ. Falciparum malaria and pregnancy. Transactions of the Royal Society of Tropical Medicine and Hygiene 73:427-431, 1979.

7. Bray RS, Sinden RE. The sequestration of Plasmodium falciparum infected erithocytes in the placenta. Tran- sactions of the Royal Society of Tropical Medicine and Hygiene 73:716-719, 1979.

8. De Silva DHG, Mendis KN, Premaratne VN, Jayatilleke SMD, Soyz AP. Congenital malaria due to Plasmodium vivax: a case reported from Sri Lanka. Transactions of the Royal Society of Tropical Medicine and Hygiene 75:33-35, 1982.

9. Gilles HM, Harinasuta T, Bunnag D. Malaria. In: Gilles HM (ed) Recent Advances in Tropical Medicine, vol. 1, C. Livingstone, New York, 1984.

10. Mc Gregor I. Malaria: Recollections and observations. Transactions of the Royal Society of Tropical Medicine and Hygiene 78:1-8, 1984.

11. Miller LH, Aikawa M, Dvorak JA. Malaria (Plasmodium knowlesi) merozoites: immunity and surface coat. Journal of Immunology 114:1237-1242, 1975.

12. Miller LH, Cooper WG, Chiem S, Fremount HN. Surface charge on Plasmodium knowlesi and $P$. coatneyi red cells of Macaca mulatta. Experimental Parasitology 32:86-95, 1972.

13. Miller LH, Fremount HN, Luse SA. Deep vascular schizogony of Plasmodium knowlesi in Macaca mulatta: Distribution in organs and ultrastructure of parasited red cells. American Journal of Tropical Medicine and Hygiene 20:816-824, 1971.

14. Playfair JHL. Immunity to malaria. British Medical Bulletin 38:153-159, 1982.

15. Walter PR, Garin Y, Blot P. Placental pathologic changes in malaria. American Journal of Pathology 109:330-342, 1982. 